\title{
Analysis of Feed Preference of Edible Termites (Isoptera) on Selected Plants and Their Crude Extract Phytochemistry
}

\author{
C. M. Ameka' ${ }^{1}$ Benard Muok¹, Helida Oyieke ${ }^{2}$ \\ ${ }^{1}$ Jaramogi Oginga Odinga University of Science and Technology, Bondo, Kenya \\ ${ }^{2}$ National Museums of Kenya, Nairobi, Kenya \\ Email: amekacaleb@gmail.com,bmuok@yahoo.com, oyiekeh@gmail.com
}

How to cite this paper: Ameka, C.M., Muok, B. and Oyieke, H. (2022) Analysis of Feed Preference of Edible Termites (Isoptera) on Selected Plants and Their Crude Extract Phytochemistry. Advances in Entomology, 10, 52-62.

https://doi.org/10.4236/ae.2022.101004

Received: October 4, 2021

Accepted: November 27, 2021

Published: November 30, 2021

Copyright (อ 2022 by author(s) and Scientific Research Publishing Inc. This work is licensed under the Creative Commons Attribution International License (CC BY 4.0).

http://creativecommons.org/licenses/by/4.0/

\begin{abstract}
Termites are social insects that inhabit colonies in the soil. Termites feed on a wide range of plants found within diverse habitats of Luanda Sub-County. This study aimed at assessing feed preference of edible termites and analyzing their phytochemical composition. Termites were exposed to ten different test plants in their natural habitats to assess feed preference. Forty-seven study sites were selected as they had high termite abundance from previous studies. The test plants were Grevillea robusta, sugarcane, maize, blue citronella grass, Eucalyptus, mango, avocado, neem, bamboo and a mixture of all the ten plants. Small pits were dug in the ground where the ten treatments were placed and replicated four times each. The test plants were placed in the evening then covered with soil block. The number of termites feeding on the test plants was counted after 12 hours the following day. There were separate trials for crushed and uncrushed feed substrates. The feed substrates that showed high feed preference was selected for phytochemical analysis. The plants whose crude extract was obtained were Grevillea robusta, bamboo, Eucalyptus, cypress, maize and sugarcane. The results for this study were analysed using one-way ANOVA. The study revealed that crushed feed substrates had a high level of feed preference by termites $p<0.05$. The mixture of all the feed substrates also showed high termite preference and a mean and SE of $676.500 \pm 41.7^{\mathrm{a}}$. Phytochemical analysis of the crude plant extracts revealed that Eucalyptus had the highest number of phytochemicals present 9 out of 12. The identified phytochemicals were saponins, tannins, alkaloids, resins, cardiac glycosides, carbohydrates, phenols and flavones.
\end{abstract}

\section{Keywords}

Termites, Substrate, Phytochemical 


\section{Introduction}

Edible termites are used as food and feed in many parts of the world [1] [2]. There are many termite species across diverse habitats in the world [3]. Termites forage on many plants found within those habitats for their dietary requirements. The choice of plants to forage on by termites is influenced by the attraction of the termite towards the plant. Plants produce phytochemicals that differ in quality and composition [4]. Some plants have a strong attraction to termites than others. In a study conducted by [5] in Arusha region of Tanzania, termites were reported to attack crops, and trees in homesteads and in the forests.

[6] documented that termites forage mainly during the rainy season and are highly limited during the dry period due to variations in feed sources. According to [7] the distribution and abundance of termites were significantly correlated with a set of environmental and ecological variables such as the presence of plants, soil organic carbon, minerals and water. [8] found that termites of the genus Macrotermes actively foraged on branches and logs of dry trees. Termites thus play a very important role in forest ecosystems and also cause significant injury to trees. [9] in his work recorded that termites primarily feed on a wide variety of food sources like tree logs, deadwood, grasses, humus and fungi. Feeding preferences of the dry wood termite Cryptotermes brevis were studied and found that only pine was foraged on in lower quantity compared to cedar. [10] recorded that carbohydrates were present in wood thus providing the required nutrients to termites. This study investigated feeding preferences of termites on ten plant species, namely, Eucalyptus, bamboo, blue citronella grass, maize, sugarcane, avocado, mango, neem, cypress, mixture and G. robusta. The study also evaluated the phytochemical composition of the plants which edible termites highly forage. The significance of this study was to document the most favourable termite attractant plant that can be used to harvest termites for food and feed.

\section{Materials and Methods}

\subsection{Determination of Feed Preferences of Termites on Selected Plants (Uncrushed and Crushed) in an Open Field Bioassay}

Test plants were selected from forty-seven termite habitats in the Luanda subcounty. The plants were sugarcane, bamboo, G. robusta, blue citronella grass, maize stems, Eucalyptus, cypress, mango, avocado, neem, and a mixture of all the test plants. The control had no feed material. A field measuring $100 \mathrm{~m}$ by 40 $\mathrm{m}$ was selected for the study. Rectangular holes measuring $25 \mathrm{~cm}$ by $15 \mathrm{~cm}$ were dug at a spacing of $3 \mathrm{~m}$ apart. There were eleven treatments replicated four times. About $200 \mathrm{~g}$ of chopped dry materials of the test plants were assigned randomly in the dug holes and covered with a soil block at $6 \mathrm{pm}$. The feed traps were checked the following day at 6 am before termites moved out. The number of termites foraging on the plant materials was removed and placed into a plastic basin, counted using forceps. This procedure was repeated in four different loca- 
tions spread $500 \mathrm{~m}$ apart. The test plants that showed high feeding preferences were selected for laboratory phytochemical screening. This procedure was repeated with crushed test plants.

\subsection{Preparation of Test Plant Material for Phytochemical Analysis}

The bark and stem of fresh mature Grevillea robusta were collected from Luanda Sub-County of Vihiga County. Forty-seven study sites were identified in $\left(34.60248 \mathrm{E}, 0.00748 \mathrm{~N}\right.$. A section of the stem was dried at $60^{\circ} \mathrm{C}$ in a cool shade for $72 \mathrm{~h}$. The resulting dried sample was ground into powder using a mill (Jehmlich, Germany) and placed in bags and transported to the National museums of Kenya for further experiments. The same procedure was repeated for Eucalyptus, sugarcane, maize, bamboo, and cypress. These were the plants that attracted a large number of termites to feed.

\subsection{Preparation of Plant Extracts}

About $200 \mathrm{~g}$ of $G$. robusta powder was soaked in Methanol and Dichloromethane at a sample: solvent ratio of $1: 20(\mathrm{w} / \mathrm{v})$ for $48 \mathrm{~h}$ at $24^{\circ} \mathrm{C}$. The mixture was filtered in glass jars over cotton wool. The crude mixture was homogenized at $60^{\circ} \mathrm{C}$ for $4 \mathrm{~h}$ using a homogenizer (IKA, Germany). The extracts were filtered using filter paper on a filter funnel. The filtrate was concentrated at $60^{\circ} \mathrm{C}$ using a rotary evaporator (Polylab, India) and freeze-dried for $24 \mathrm{~h}$. All the freeze-dried extracts were stored at $4^{\circ} \mathrm{C}$ before further tests were performed as documented by [11] [12] with minor modifications.

\subsection{Analysis of Alkaloids}

Alkaloids were analysed using Dragendorffs test. $2 \mathrm{mg}$ of the methanolic extract was placed in a test tube and $5 \mathrm{ml}$ of distilled water was added to the mixture. $2 \mathrm{M}$ Hydrochloric acid was added to the mixture until an effervescence reaction occurred. To the mixture, $1 \mathrm{ml}$ of Dragendorff's reagent was added and shaken. Formation of orange or orange-red precipitate signified the presence of alkaloids.

\subsection{Analysis of Reducing Sugars-Benedicts Test}

About $2 \mathrm{mg}$ of methanolic extract was shaken with $10 \mathrm{ml}$ of distilled water in a test tube, filtered, and the filtrate was concentrated. To the concentrate $5 \mathrm{ml}$ of Benedict's solution was added and the mixture was boiled for 5 minutes. Formation of brick red-colored precipitate showed the presence of carbohydrates.

\subsection{Detection of Carbohydrates-Molisch's Test}

Approximately $2 \mathrm{mg}$ of methanolic extract was mixed with $10 \mathrm{ml}$ of distilled water in a test tube, filtered and concentrated. Two drops of freshly prepared $20 \%$ alcoholic solution of $\alpha$-naphthol were added to the filtrate and shaken. $2 \mathrm{ml}$ of concentrated sulphuric acid was added to the mixture so as to form a layer below 
the mixture. Red-violet ring appeared, signifying carbohydrates which disappeared on addition of excess alkali.

\subsection{Detection of Monosaccharides-The Barfoed's Test}

About $1 \mathrm{ml}$ of the test sample was placed in a dry test tube. $1 \mathrm{ml}$ of distilled water was placed in another tube as control experiment. $2 \mathrm{ml}$ of Barfoed's reagent was added in all tubes and Kept in boiling water bath. Time taken to develop a brick red colour was observed.

\subsection{Analysis of Flavonoids}

Flavonoids were analysed according to the method described [13] the Shinoda test. About $2 \mathrm{mg}$ of methanolic extract was dissolved in $5 \mathrm{ml}$ of ethanol in a test tube and shaken. To the mixture, about 10 drops of dilute hydrochloric acid were added followed by a piece of magnesium. Formation of pink, reddish or brown colour indicated presence of flavonoids.

\subsection{Detection of Glycosides}

Approximately $2 \mathrm{mg}$ of the extract was shaken with $10 \mathrm{ml}$ of water in a test tube, filtered, and the filtrate concentrated. To the filtrate, 2 - 3 drops of Molisch's reagent were added together with $2 \mathrm{ml}$ of concentrated sulphuric acid, carefully through the side of the test tube. A reddish violet ring appeared signifying the presence of glycosides.

\subsubsection{Detection of Triterpenoids}

The Liebermann-Burchard's test was used. About $2 \mathrm{mg}$ of the dry extract was dissolved in acetic anhydride in a test tube, heated to boiling, cooled and then 1 $\mathrm{ml}$ of concentrated sulphuric acid was added to the mixture along the sides of the test tube. The appearance of pink colour indicated the presence of triterpenoids.

\subsubsection{Detection of Resins}

Resins were analysed according to the method described by [14]. About $1 \mathrm{ml}$ of methanolic extract was dissolved in acetone in a test tube and distilled water was added to the mixture. Turbidity showed the presence of resins.

\subsubsection{Detection of Saponins}

One drop of sodium bicarbonate solution was added to a test tube containing 5 $\mathrm{ml}$ of methanolic extract in a test tube and shaken. The formation of honeycomb-like structure indicates the presence of saponins.

\subsubsection{Detection of Steroids}

Approximately $2 \mathrm{mg}$ of dry extract was dissolved in acetic anhydride and heated to boiling, cooled, and then $1 \mathrm{ml}$ of concentrated sulphuric acid was carefully added along the sides of the test tube. The occurrence of green colour indicated steroids presence. 


\subsubsection{Detection of Tannins}

Tannins were analysed according to the method described by [15]. About $1-2$ $\mathrm{ml}$ of the ethanolic extract, few drops of $5 \% \mathrm{w} / \mathrm{v}$ Iron(III) chloride solution was added in a test tube and the mixture shaken. A green colour showed the presence of gallotannins, while brown colour signified the presence of pseudotannins.

Note

These tests were repeated on samples of Eucalyptus, sugarcane, maize, bamboo, and cypress.

\subsubsection{Data Analysis}

Data analysis was carried out in one-way ANOVA for all the experiments. The experimental data was subjected to Least Significant Difference (LSD) test and the significant differences were marked with different alphabet letters.

\section{Results and Discussion}

\subsection{Evaluation of Uncrushed Feed Substrates}

This study envisaged to find out how termites respond to different plant substrates as food. Could avocado attract termites differently than G. robusta, Eucalyptus, cypress, neem, mango, maize, sugarcane, bamboo, blue citronella grass? and what would be the effect of having no substrate? One-way analysis of variance (ANOVA) followed by the least significant difference (LSD) test showed statistical significance $(\mathrm{p}<0.05)$ compared to control (Table 1 and Table 2).

Table 1. Analysis of variance (ANOVA) table for uncrushed feed substrates.

\begin{tabular}{cccccc}
\hline & Df & Sum Sq. & Mean Sq. & F value & $\operatorname{Pr}(>\mathrm{F})$ \\
\hline substrate & 11 & $4,601,105$ & 418,282 & 34.42 & $<2 \mathrm{e}-16^{* * *}$ \\
termite & 1 & $1,072,940$ & $1,072,940$ & 88.29 & $1.05 \mathrm{e}-14^{* * *}$ \\
Residuals & 83 & $1,008,683$ & 12,153 & & \\
\hline
\end{tabular}

Table 2. Least significant difference(LSD) Means and SE for uncrushed feed substrates.

\begin{tabular}{cc}
\hline Substrate & Mean \pm SE \\
\hline Mixture & $676.500 \pm 41.7^{\mathrm{a}}$ \\
Sugarcane & $552.500 \pm 33.7^{\mathrm{ab}}$ \\
Grevilea & $499.625 \pm 34.2^{\mathrm{bc}}$ \\
Bamboo & $475.500 \pm 29.2^{\mathrm{bc}}$ \\
Maize & $425.000 \pm 34.5^{\mathrm{cd}}$ \\
Cypress & $326.625 \pm 24.6^{\mathrm{de}}$ \\
Eucalyptus & $312.375 \pm 33.3^{\mathrm{e}}$ \\
Neem & $312.375 \pm 11.6^{\mathrm{e}}$ \\
Avocado & $141.875 \pm 10.5^{\mathrm{f}}$ \\
Mango & $77.500 \pm 12.8^{\mathrm{fg}}$ \\
Blue citronella & $18.500 \pm 0.26^{\mathrm{g}}$ \\
Control & $0.625 \pm 0.09^{\mathrm{g}}$ \\
\hline
\end{tabular}


Luanda Sub-County has many tree species among them Grevillea, cypress, Eucalyptus, neem, mango, avocado. A mixture of all the plant species gave the highest termite attraction (Mean \pm SE, $676.500 \pm 41.7^{\text {ab }}$ ) followed by sugarcane $\left(552.500 \pm 33.7^{\mathrm{ab}}\right)$, while the blue citronella grass had the lowest attraction $\left(18.500 \pm 0.26^{\mathrm{g}}\right)($ Table 2$)$.

In this study, the least significant difference was calculated and significant differences were marked with a different alphabet. Similar letters are statistically not significant. Sugarcane, grevillea and maize are not different they had the same level of attraction thus marked with same alphabet letter superscript. While Grevilea, bamboo, and maize had the same level of attraction. Maize and cypress had the same level of attractiveness. Cypress and Eucalyptus had the same level of attractivity. Neem, avocado and mango had the same level of attractiveness. Avocado, Mango, blue citronella grass and control had the same level of attractiveness. LSD value followed by same letter show the same level of attractiveness. Blue citronella grass was not attractive to termites just like in the control pits where there was feed substrate.

Termites visited the feed traps at night as they prefer feeding in darkness. Variation in wood chemistry is known to affect termite feeding and substrate preference. In his study [16] recorded that termites prefer small blocks of wood to large blocks. In this study, the selected plants were chopped into small pieces and put in the termite traps. Among the tree species used in this study, Grevillea had the highest attraction followed by Eucalyptus and cypress respectively. [17] reported that termites foraged on Eucalyptus. [18] reported that Eucalyptus species are highly susceptible to termites.

The worker termites were found in large numbers than soldiers. The workers feed while the soldiers keep guard. Worker termites produce a loud noise when chewing. This loud chewing generates acoustic emissions that attract more workers to feed in the dark, as elucidated by [19].

\subsection{Evaluation Crushed Feed Substrates}

In the crushed feed bioassay, the mixture had the highest mean of termite attraction $\left(772.25 \pm 41.7^{\mathrm{ab}}\right)$ while blue citronella grass had the lowest $\left(4.37 \pm 0.26^{\mathrm{g}}\right)$ the control had $\left(1.00 \pm 0.09^{\mathrm{g}}\right)$. The termites were attracted to the crushed feed substrate $\mathrm{p}$ value was very significant $\mathrm{p}<0.05$ (Table 3 ).

When crushed feed is used, the feed attractiveness was higher $\left(772.25 \pm 41.7^{\mathrm{ab}}\right)$ Table 2 compared to uncrushed $\left(676.500 \pm 41.7 \mathrm{a}^{\text {ab }}\right)$ (Table 4).

Table 3. Analysis of variance table for crushed feed substrates.

\begin{tabular}{cccccc}
\hline & Df & Sum Sq. & Mean Sq. & F value & $\operatorname{Pr}(>$ F $)$ \\
\hline substrate & 11 & $6,045,179$ & 549,562 & 34.26 & $<2 \mathrm{e}-16^{* * *}$ \\
termite & 1 & $2,344,063$ & $2,344,063$ & 146.15 & $<2 \mathrm{e}-16^{* * *}$ \\
Residuals & 83 & $1,331,227$ & 16,039 & & \\
\hline
\end{tabular}


Table 4. LSD, Mean termite count and SE of crushed feed substrates.

\begin{tabular}{cc}
\hline Substrate & Mean \pm SE \\
Mixture & $772.25 \pm 41.7^{\mathrm{a}}$ \\
Maize & $668.62 \pm 34.5^{\mathrm{ab}}$ \\
Grevillea & $622.37 \pm 34.2^{\mathrm{bc}}$ \\
Sugarcane & $591.00 \pm 33.7^{\mathrm{bcd}}$ \\
Eucalyptus & $534.87 \pm 33.3^{\text {cde }}$ \\
Bamboo & $469.12 \pm 29.2^{\mathrm{de}}$ \\
Cypress & $411.12 \pm 24.6^{\mathrm{e}}$ \\
Mango & $218.00 \pm 12.8^{\mathrm{f}}$ \\
Avocado & $195.25 \pm 10.5^{\mathrm{f}}$ \\
Neem & $184.87 \pm 11.6^{\mathrm{f}}$ \\
Blue citronella & $4.37 \pm 0.26^{\mathrm{g}}$ \\
Control & $1.00 \pm 0.09^{\mathrm{g}}$
\end{tabular}

The mixture had the highest level of attraction $\left(772.250^{\mathrm{a}}\right)$, while blue citronella had the least attraction (4.375). Sugarcane, maize, Grevilea and sugarcane had the same level of attractiveness by termites. Maize and mixture had the same effects (a, ab). Sugarcane, Bamboo, and Eucalyptus have the same effects on termite attractiveness. Eucalyptus, Bamboo and cypress have the same effects. Mango Avocado and neem have the same level of attraction but much lower than the rest. Blue citronella and control had the same effects. [20] recorded that wood-feeding termites can digest up to $85 \%$ and $83 \%$ of glucosyl and xylosyl residues from lignocellulose, respectively. Predigested diets will give termites ample time to forage faster than uncrushed feed substrates.

\subsection{Qualitative Phytochemical Analysis of Termite Feed}

Test plants, including G. robusta, Eucalyptus, bamboo, sugarcane, maize, and cypress were evaluated for the presence of phytochemicals. Saponins were present in all termite feed substrates, excluding Grevilea. Eucalyptus had the highest quantities $(+++)$ Table 5, while sugarcane had the least $(+)$. [21] isolated saponins in Periandra dulcis roots evidence of the presence of Saponins in plants.

Flavonoids were present in Eucalyptus alone, while triterpenoids were present in cypress. Flavonoids were absent in all the plant samples tested. On the other hand, resins and carbohydrates were present in all the plant species tested.

Tannins were present in large quantities in sugarcane, G. robusta and Eucalyptus (+++), while bamboo, cypress and maize were absent. [22] also documented that tannins were present in Samanea saman pods. Alkaloids are organic compounds that contain nitrogen an important element in insect diets as recorded by [23]. Alkaloids were present in G. robusta and Eucalyptus in large quantities $(+++)$, while in bamboo, small quantities were present $(+)$. Sugarcane, 
Table 5. Qualitative phytochemical screening of plant metabolites from selected edible termite feed substrates.

\begin{tabular}{cccccccc}
\hline \multicolumn{7}{c}{ Sample } \\
\hline No & Phytochemical Test & Bambo 0 Sugarcane & Cypress & G. robusta & Maize Eucalyptus \\
\hline 1. & Saponins & ++ & + & ++ & - & + & +++ \\
2. & Tannins & - & +++ & - & +++ & - & +++ \\
3. & Alkaloids & + & - & - & +++ & - & +++ \\
4. & Flavonoids & - & - & - & - & - & +++ \\
5. & Sterols & +++ & +++ & - & - & +++ & - \\
6 & Resins & ++ & ++ & ++ & +++ & ++ & +++ \\
7. & Triterpenoids & - & - & +++ & - & - & - \\
8 & Cardiac Glycosides & +++ & - & + & - & - & +++ \\
9. & Carbohydrates & ++ & +++ & ++ & +++ & +++ & + \\
10. & Reducing sugars & + & +++ & - & + & +++ & - \\
11. & Flavones & - & - & - & - & - & - \\
12 & Phenols & - & ++ & + & +++ & +++ & +++ \\
\hline
\end{tabular}

Key +++ means present in large quantities; ++ means present in moderate quantities; + means present in small quantities.

cypress and maize alkaloids were absent. [24] also documented the presence of alkaloids in cypress. Flavonoids were present in Eucalyptus in large quantities $(+++)$ but absent in the rest. In his study [25] reported that Eucalyptus maculate had three flavonoids isolated. Sterols were present in large quantities in Bamboo, Sugarcane and maize (+++) but absent in cypress, G. robusta and Eucalyptus.

Resins were present in all the six feed substrates but were found in large quantities in G. robusta and Eucalyptus (+++) but moderate in bamboo, sugarcane, cypress and maize. [26] documented that Resins were also present in confers a termite feed in the temperate countries. Triterpenoids were present in cypress only in large quantities $(+++)$ but were absent in the rest. This shows why termites do not forage on cypress in large quantities. Cardiac glycosides were present in bamboo and Eucalyptus in large quantities (+++), while cypress had small quantities (+). Sugarcane, G. robusta, and maize had no cardiac glycosides. Carbohydrates were present in all feed substrates with sugarcane, maize and $G$. robusta having large quantities (+++). A study conducted by [27] recorded that two Cameroonian medicinal plants, Duboscia macrocarpa and Canarium schweinfurthii contained triterpenes dubosic acid, while bamboo and cypress had carbohydrates in moderate quantities (++). Eucalyptus had carbohydrates in small quantities. In his study [28] analysed the presence of carbohydrates in Eucalyptus. Reducing sugars were found in maize in large quantities (+++) while bamboo and $G$. robusta in small quantities. Sugars are important in the diet of insects mainly termites as they are a major source of energy. Cypress and Euca- 
lyptus had none. Reducing sugars present. [29] showed that fructose and Glucose levels were significantly higher in sugarcane. Flavones were absent in all the feed substrates. Phenols were present from Maize, G. robusta and Eucalyptus in large quantities $(+++)$, while sugarcane had moderate quantities $(++)$. Cypress had small quantities $(+)$, while bamboo had none. Phenols are crucial in the development of termites thus diets containing phenols were preferred by termites. Flavones play a role in providing colour, smell and taste in selected plants which makes them attractants for insect birds and mammals described by [30]. [31] noted that the excessive use of plants containing Alkaloids should be used sparingly as some contain antifeedant activity to insects.

\section{Conclusion}

Termites forage on plants with a variety of phytochemicals. Among them are saponins, resins and carbohydrates which were found present in all termite feed substrates. Crushed feed substrates are preferred by termites than non-crushed feed substrates. This enables them to forage faster. Plants rich in sugars are also an ideal feed for termites.

\section{Acknowledgements}

The present study has been granted by the world bank ACEII grant to Jaramogi Oginga Odinga University of science and technology, Kenya. We thank the technical staff at the National museums of Kenya, who were supportive throughout the study.

\section{Conflicts of Interest}

The authors declare no conflicts of interest regarding the publication of this paper.

\section{References}

[1] Kenis, M., Koné, N., Chrysostome, C.A.A.M., Devic, E., Koko, G.K.D., Clottey, V.A., Nacambo, S. and Mensah, G.A. (2014) Insects Used for Animal Feed in West Africa. Entomologia, 2, 107-114. https://doi.org/10.4081/entomologia.2014.218

[2] Ayieko, M., Ndong'a, F. and Tamale, A. (2010) Climate Change and the Abundance of Edible Insects in the Lake Victoria Region. Journal of Cell and Animal Biology, 4, 112-118.

[3] Pranesh, M.K. and Harini, B.P. (2015) Diversity and Distribution Pattern of Termites in Relation with Human Interference: A Study at Jnanabharathi Campus, Bangalore, India. The Ecoscan, 9, 671-676.

[4] Fraga-Corral, M., García-Oliveira, P., Pereira, A.G., Lourenço-Lopes, C., Jimenez-Lopez, C., Prieto, M.A. and Simal-Gandara, J. (2020) Technological Application of Tannin-Based Extracts. Molecules, 25, Article No. 614. https://doi.org/10.3390/molecules25030614

[5] James, S., Ndakidemi, P.A. and Mbega, E.R. (2020) Effects of Selected Pesticidal Plants on Termites Affecting Maize Production in Arusha, Tanzania. American Journal of Plant Sciences, 11, 510-527. https://doi.org/10.4236/ajps.2020.113036 
[6] Materu, C., Yarro, J., Nyundo, B., Materu, C.L. and Nyundo, B.A. (2013) Seasonal Changes on Termite Foraging Behaviour under Different Habitats in Rufiji District Tanzania. Journal of Biology, Agriculture and Healthcare, 3, 6-12.

[7] Korb, J., Kasseney, B.D., Cakpo, Y.T., Casalla Daza, R.H., Gbenyedji, J.N.K.B., Ilboudo, M.E., Josens, G., Koné, N.A., Meusemann, K., Ndiaye, A.B., Okweche, S.I., Poulsen, M., Roisin, Y. and Sankara, F. (2019) Termite Taxonomy, Challenges and Prospects: West Africa, A Case Example. Insects, 10, Article No. 32.

https://doi.org/10.3390/insects10010032

[8] Rao, A.N., Samatha, C. and Sammaiah, C. (2012) Bio-Diversity of Termites in Bhadrachalam Forest Region, Khammam District, Andhra Pradesh. Journal of Biodiversity, 3, 55-59. https://doi.org/10.1080/09766901.2012.11884736

[9] Ravan, S., Khan, I.A. and Manzoor, F. (2015) Feeding Habitats and Wood Preferences of Termites in Iran. Journal of Entomology and Zoology Studies, 3, 20-23.

[10] Poissonnier, L.A., Arganda, S., Simpson, S.J., Dussutour, A. and Buhl, J. (2018) Nutrition in Extreme Food Specialists: An Illustration Using Termites. Functional Ecology, 32, 2531-2541. https://doi.org/10.1111/1365-2435.13200

[11] Murthy, K.S.S., Banu, Y.L. and Ramakrishna, P. (2017) Diversity of Subterranean Termites in South India Based on COI Gene. Journal of Biodiversity, Bioprospecting and Development, 4, Article No. 161.

https://doi.org/10.4172/2376-0214.1000161

[12] Altemimi, A., Lakhssassi, N., Baharlouei, A., Watson, D.G. and Lightfoot, D.A. (2017) Phytochemicals: Extraction, Isolation, and Identification of Bioactive Compounds from Plant Extracts. Plants, 6, Article No. 42. https://doi.org/10.3390/plants6040042

[13] Abubakar, A.R. and Haque, M. (2020) Preparation of Medicinal Plants: Basic Extraction and Fractionation Procedures for Experimental Purposes. Journal of Pharmacy and Bioallied Sciences, 12, 1-10. https://doi.org/10.4103/jpbs.JPBS_175_19

[14] Brunni, A., De Castro, C., William, A. and De Sousa, J.C. (2019) Knowledge Management for Agricultural Development. Agricultural Research \& Technology Open Access Journal, 22, 109-112.

[15] Schoefied, P., Mbugua, D. and Pell, A.N. (2016) Analysis of Condensed Tannins: A Review. Animal Feed Science and Technology, 91, 21-40. https://doi.org/10.1016/S0377-8401(01)00228-0

[16] Evans, T.A., Lai, J.C.S., Toledano, E., McDowall, L., Rakotonarivo, S. and Lenz, M. (2005) Termites Assess Wood Size by Using Vibration Signals. Proceedings of the National Academy of Sciences of the United States of America, 102, 3732-3737. https://doi.org/10.1073/pnas.0408649102

[17] Fajar, A., Himmi, S.K., Latif, A., Tarmadi, D., Kartika, T., Guswenrivo, I., Yusuf, S. and Yoshimura, T. (2021) Termite Assemblage and Damage on Tree Trunks in Fast-Growing Teak Plantations of Different Age: A Case Study in West Java, Indonesia. Insects, 12, Article No. 295. https://doi.org/10.3390/insects12040295

[18] Nakabonge, G. and Matovu, B. (2021) Variation in Susceptibility of Eucalyptus grandis and Selected Hybrid Clones to Two Termite Species Macrotermes bellicosus and M. subhyalinus in Uganda. All Life, 14, 120-126. https://doi.org/10.1080/26895293.2021.1883126

[19] Wang, M., Buček, A., Šobotník, J., Sillam-Dussès, D., Evans, T.A., Roisin, Y., Lo, N. and Bourguignon, T. (2019) Historical Biogeography of the Termite Clade Rhinotermitinae (Blattodea: Isoptera). Molecular Phylogenetics and Evolution, 132, 100 104. https://doi.org/10.1016/j.ympev.2018.11.005 
[20] Tarayre, C., Bauwens, J., Mattéotti, C., Brasseur, C., Millet, C., Massart, S., Destain, J., Vandenbol, M., De Pauw, E., Haubruge, E., Francis, F., Thonart, P., Portetelle, D. and Delvigne, F. (2015) Multiple Analyses of Microbial Communities Applied to the Gut of the Wood-Feeding Termite Reticulitermes flavipes Fed on Artificial Diets. Symbiosis, 65, 143-155. https://doi.org/10.1007/s13199-015-0328-0

[21] Negri, G. and Tabach, R. (2013) Saponins, Tannins and Flavonols Found in Hydroethanolic Extract from Periandra dulcis Roots. Revista Brasileira de Farmacognosia, 23, 851-860. https://doi.org/10.1590/S0102-695X2013000600001

[22] Ukoha, P.O., Cemaluk, E.A.C., Nnamdi, O.L. and Madus, E.P. (2011) Tannins and Other Phytochemical of the Samanaea saman Pods and Their Antimicrobial Activities. African Journal of Pure and Applied Chemistry, 5, 237-244.

http://www.academicjournals.org/AJPAC

[23] Matsuura, H.N. and Fett-Neto, A.G. (2015) Plant Alkaloids: Main Features, Toxicity, and Mechanisms of Action. In: Gopalakrishnakone, P., Carlini, C. and Ligabue-Braun, R., Eds., Plant Toxins, Springer, Dordrecht, 1-15. https://doi.org/10.1007/978-94-007-6728-7_2-1

[24] Azzaz, N., Hamed, S. and Kenawy, T. (2019) Chemical Studies on Cypress Leaves (Cupressus sempervirens) and Their Activity as Antimicrobial Agents. Al-Azhar Journal of Agricultural Research, 44, 100-109. https://doi.org/10.21608/ajar.2019.102641

[25] Takahashi, T., Kokubo, R. and Sakaino, M. (2004) Antimicrobial Activities of Eucalyptus Leaf Extracts and Flavonoids from Eucalyptus maculata. Letters in Applied Microbiology, 39, 60-64. https://doi.org/10.1111/j.1472-765X.2004.01538.x

[26] Simoneit, B.R.T., Otto, A., Oros, D.R. and Kusumoto, N. (2019) Terpenoids of the Swamp Cypress Subfamily (Taxodioideae), Cupressaceae, an Overview by GC-MS. Molecules, 24, Article No. 3036. https://doi.org/10.3390/molecules24173036

[27] Sandjo, L.P. and Kuete, V. (2013) Triterpenes and Steroids from the Medicinal Plants of Africa. In: Kuete, V., Ed., Medicinal Plant Research in Africa: Pharmacology and Chemistry, Elsevier Inc., Amsterdam, 135-202. https://doi.org/10.1016/B978-0-12-405927-6.00004-7

[28] Alves, E.F., Bose, S.K., Francis, R.C., Colodette, J.L., Iakovlev, M. and Van Heiningen, A. (2010) Carbohydrate Composition of Eucalyptus, Bagasse and Bamboo by a Combination of Methods. Carbohydrate Polymers, 82, 1097-1101.

https://doi.org/10.1016/j.carbpol.2010.06.038

[29] Pereira, L.F.M., Ferreira, V.M., de Oliveira, N.G., Sarmento, P.L.V.S., Endres, L. and Teodoro, I. (2017) Sugars Levels of Four Sugarcane Genotypes in Different Stem Portions during the Maturation Phase. Anais Da Academia Brasileira de Ciencias, 89, 1231-1242. https://doi.org/10.1590/0001-3765201720160594

[30] Mierziak, J., Kostyn, K. and Kulma, A. (2014) Flavonoids as Important Molecules of Plant Interactions with the Environment. Molecules, 19, 16240-16265. https://doi.org/10.3390/molecules191016240

[31] Jeyasankar, A., Premalatha, S. and Elumalai, K. (2014) Antifeedant and Insecticidal Activities of Selected Plant Extracts against Epilachna Beetle, Henosepilachna vigintioctopunctata (Coleoptera: Coccinellidae). Advances in Entomology, 2, 14-19. https://doi.org/10.4236/ae.2014.21003 